\title{
Cd-proline Complex Catalyzed Direct one-Pot three Component Mannich Reaction in Water Medium
}

\author{
Soniya D. Moirangthem, Bhavna Thingom, Warjeet S. Laitonjam* \\ Department of Chemistry, Manipur University, Canchipur - 795 003, Manipur, India \\ warjeet@yahoo.com
}

\section{ABSTRACT}

Metal-proline complexes of various metals like $\mathrm{Zn}, \mathrm{Cd}, \mathrm{Hg}$, and $\mathrm{Pb}$ were found to be good catalysts for direct Mannich reaction in water medium at room temperature, smoothly affording the $\beta$-amino carbonyl compounds in excellent yields. Among the catalyst cadmium-proline complex gave high yield in lesser time. All the catalysts were easily separated from the reaction mixture by water extraction and among this cadmium -proline complex was found to be most stable and can be recycled five times without losing its catalytic activity.

\section{Indexing terms/Keywords}

Cadmium-proline; Metal acetate; Mannich reaction; Water medium.

\section{Academic Discipline And Sub-Disciplines}

Chemistry

\section{SUBJECT CLASSIFICATION}

Organic Chemistry

\section{TYPE (METHOD/APPROACH)}

Organic Synthetic Chemistry

\section{$\underline{\text { Council for Innovative Research }}$}

Peer Review Research Publishing System

Journal: Journal of Advances in Chemistry

Vol. 7, No. 1

editor@cirworld.com

www.cirworld.com, member.cirworld.com 


\section{INTRODUCTION}

The development of catalytic multi-component reactions in water medium has now become the most challenging area in the current chemistry [1-4]. Due to low cost, safety and environmentally benign nature, the use of water as a sole medium for organic reactions greatly contribute to the modern green synthetic methods [5-6]. Most of the industry prefers to use water as a solvent rather than a toxic organic solvent. In recent years, many of the researchers were focused on the multicomponent reactions in water medium like Pesserini [7] and Ugi [8] reactions.

The Mannich reaction is one of the most important carbon-carbon bond forming reaction which afforded mainly $\beta$-amino carbonyl compounds [9]. The products of the Mannich reactions are the valuable synthetic intermediates for various pharmaceuticals and natural products [10]. The increasing popularity of the Mannich reaction was found by the ubiquitous nature of nitrogen containing compounds in drugs and natural products in the pharmaceutical researches [11]. In the modern version of the Mannich reaction, many drawbacks have been developed by using water as reaction medium in presence of catalyst in one step process of one-pot three component strategy. Most of the researchers explored Mannich reaction using water as a reaction medium in presence of a catalyst with high yields and enantioselectivities. Mainly the catalyst for the reaction involved Heteropoly acids [12], Ionic liquids [13], Lipase [14], Siloxy proline tetrazole [15] and Lthreonine derived organocatalyst [16]. Kobayashi and co-workers explored the Mannich type reaction in $\mathrm{H}_{2} \mathrm{O}$ /tetrahydrofuran(THF) medium by using a combination of $\mathrm{ZnF}_{2}$ and a chiral diamine as a catalyst [17]. Barbas and Cordova also explored the Mannich type reaction in $\mathrm{H}_{2} \mathrm{O} / \mathrm{THF}$ medium by using L-proline as organocatalyst for the reaction [18].

Our recent interest has been focused on the development of metal-proline complexes as organocatalysts for organic reaction in water medium. For the first time Darbre and Machuqueiro reported the $\mathrm{Zn}$ (proline) ${ }_{2}$ complex as highly enantioselective and competent catalyst for direct aldol reaction in aqueous media [19] and further studies of $\mathrm{Zn}$-proline complex was done by many researchers in the synthesis of Pyrazole [20] and Pyrimidine derivative [21] in different solvents. In continuation of our ongoing studies on the synthesis of new variants of metal-proline complexes and to investigate the catalytic activities in water medium, here we report the use of metal-proline complexes for one-pot three component Mannich reactions and the possibility of catalyst recycling.

\section{EXPERIMENTAL}

\section{General procedure}

All chemicals were used without further purification and all the aldehydes, ketones, amines and metal acetates were obtained from Merck and $\mathrm{Hi}$ Media. Melting points were measured on a melting point apparatus (VMP-I) and are uncorrected. The IR spectra were recorded as $\mathrm{KBr}$ pellets on FT-IR Shimazdu IR-408 spectrometer. Absorption maxima were recorded in wave numbers $\left(\mathrm{cm}^{-1}\right)$. ${ }^{1} \mathrm{H}$ NMR spectra were recorded on Bruker AC-400 spectrometers. ${ }^{13} \mathrm{C}$ NMR spectra were recorded on Bruker $\mathrm{AC}-100 \mathrm{MHz}$ spectrometers. Residual non-deuterated solvent was used as an internal reference and all chemical shifts $\left(\delta_{H}\right.$ and $\left.\delta_{C}\right)$ are quoted in parts per million $(\mathrm{ppm})$ downfield from tetramethylsilane (TMS). Powder XRD patterns were taken on PANanalytical, X'Pert-PRO Diffractometer system of Cuka, $1.54060 \AA$. UV visible Spectra were recorded on UV visible Spectrophotometer (Perkin Elmer-LAMDA 35) and Fluorescence spectra on Perkin Elmer Spectrophotometer (LS-55).

\section{Zinc-proline complex}

To a solution of L-proline $(5.0 \mathrm{mmol})$ in $\mathrm{MeOH}(10.0 \mathrm{~mL}), \mathrm{Et}_{3} \mathrm{~N}(0.7 \mathrm{~mL})$ was added and stirred at room temperature. After $10 \mathrm{~min}$, zinc acetate $(2.5 \mathrm{mmol})$ was added; the solid which separated after 45 minutes was filtered off and recrystallized. White amorphous solid; Yield=100\%; IR $\left(\mathrm{KBr}, \mathrm{cm}^{-1}\right): 3217,2962,1605,1447,1335 ;{ }^{1} \mathrm{H}$ NMR $\left(300 \mathrm{MHz}, \mathrm{D}_{2} \mathrm{O}\right): \delta_{\mathrm{H}} 1.81(\mathrm{~m}$ br, 3H), $2.22(\mathrm{~m} \mathrm{br}, 1 \mathrm{H}), 2.96(\mathrm{~s} \mathrm{br}, 1 \mathrm{H}), 3.14(\mathrm{~m} \mathrm{br}, 1 \mathrm{H}), 3.82(\mathrm{~m} \mathrm{br}, 1 \mathrm{H}) ;{ }^{13} \mathrm{C}$ NMR $\left(75 \mathrm{MHz}, \mathrm{D}_{2} \mathrm{O}\right): \delta_{\mathrm{C}} 24.9\left(\mathrm{CH}_{2}-\mathrm{C}\right), 31.4$ $\left(\mathrm{CH}_{2}-\mathrm{NH}\right), 47.2\left(\mathrm{CH}_{2}-\mathrm{C}\right), 59.8(\mathrm{CH}-\mathrm{CO}) ; \mathrm{MS}\left(\mathrm{D}_{2} \mathrm{O}\right) \mathrm{m} / \mathrm{z}: 291[\mathrm{M}]^{+}$.

\section{Cadmium-proline complex}

To a solution of L-proline $(5.0 \mathrm{mmol})$ in $\mathrm{MeOH}(10.0 \mathrm{~mL}), \mathrm{Et}_{3} \mathrm{~N}(0.7 \mathrm{~mL})$ was added and stirred at room temperature. After $10 \mathrm{~min}$, cadmium acetate $(2.5 \mathrm{mmol})$ was added; the solid which separated after 45 minutes was filtered off and recrystallized. White amorphous solid; Yield $=100 \%$; m.p. $=$ decomposed at $240^{\circ} \mathrm{C}$; IR $\left(\mathrm{KBr}, \mathrm{cm}^{-1}\right): 3269,3202,2964,1575$, 1389; ${ }^{1} \mathrm{H}$ NMR $\left(300 \mathrm{MHz}, \mathrm{D}_{2} \mathrm{O}\right): \delta_{\mathrm{H}} 1.66(\mathrm{~m} \mathrm{br}, 3 \mathrm{H}), 2.12(\mathrm{~m} \mathrm{br}, 1 \mathrm{H}), 2.76(\mathrm{~s} \mathrm{br}, 1 \mathrm{H}), 3.03(\mathrm{~m} \mathrm{br}, 1 \mathrm{H}), 3.70(\mathrm{~m} \mathrm{br}, 1 \mathrm{H}) ;{ }^{13} \mathrm{C}$ NMR $\left(75 \mathrm{MHz}, \mathrm{D}_{2} \mathrm{O}\right)$ : $\delta_{\mathrm{C}} 25.7\left(\mathrm{CH}_{2}-\mathrm{C}\right), 30.1\left(\mathrm{CH}_{2}-\mathrm{NH}\right), 47.8\left(\mathrm{CH}_{2}-\mathrm{C}\right), 60.7(\mathrm{CH}-\mathrm{CO}) ; \mathrm{MS}\left(\mathrm{D}_{2} \mathrm{O}\right) \mathrm{m} / z: 358\left[\mathrm{M}+\mathrm{H}_{2} \mathrm{O}\right] ; A n a l$ Cald for $\mathrm{C}_{10} \mathrm{H}_{16} \mathrm{CdN}_{2} \mathrm{O}_{4}$ : C, 35.26; $\mathrm{H}, 4.73 ; \mathrm{N}, 8.22$. Found: C, 35.19; H, 4.69; N, 8.20.

\section{Mercury-proline complex}

To a solution of L-proline $(5.0 \mathrm{mmol})$ in $\mathrm{MeOH}(10.0 \mathrm{~mL}), \mathrm{Et}_{3} \mathrm{~N}(0.7 \mathrm{~mL})$ was added and stirred at room temperature. After $10 \mathrm{~min}$, mercuric acetate $(2.5 \mathrm{mmol})$ was added; the solid which separated after 45 minutes was filtered off and recrystallized.White amorphous solid ; Yield $=100 \%$; m.p. $=$ decomposed at $250^{\circ} \mathrm{C}$; IR $\left(\mathrm{KBr}, \mathrm{cm}^{-1}\right): 3543,3231,2974,1615$, 1424, 1070; ${ }^{1} \mathrm{H}$ NMR $\left(300 \mathrm{MHz}, \mathrm{D}_{2} \mathrm{O}\right)$ : $\delta_{\mathrm{H}} 1.56(\mathrm{~m} \mathrm{br}, 3 \mathrm{H}), 1.96(\mathrm{~m} \mathrm{br}, 1 \mathrm{H}), 2.79(\mathrm{~m} \mathrm{br}, 1 \mathrm{H}), 3.06(\mathrm{~s} \mathrm{br}, 1 \mathrm{H}), 3.72(\mathrm{~m} \mathrm{br}, 1 \mathrm{H}) ;$ ${ }^{13} \mathrm{C}$ NMR $\left(75 \mathrm{MHz}, \mathrm{D}_{2} \mathrm{O}\right): \delta_{\mathrm{C}} 24.7\left(-\mathrm{CH}_{2}-\mathrm{C}\right), 29.2\left(-\mathrm{CH}_{2}-\mathrm{NH}\right), 51.7\left(-\mathrm{CH}_{2}-\mathrm{C}\right), 61.9(-\mathrm{CH}-\mathrm{CO}), 178.6(-\mathrm{CO}) ; \mathrm{MS}\left(\mathrm{D}_{2} \mathrm{O}\right) \mathrm{m} / \mathrm{z}$ : $428\left[\mathrm{M}^{+}\right], 429[\mathrm{M}+\mathrm{H}], 447\left[\mathrm{M}+\mathrm{H}_{2} \mathrm{O}\right], 467[\mathrm{M}+\mathrm{K}]$; Anal Cald for $\mathrm{C}_{10} \mathrm{H}_{16} \mathrm{HgN}_{2} \mathrm{O}_{4}: \mathrm{C}, 28.01 ; \mathrm{H}, 3.76 ; \mathrm{N}, 6.53$. Found: C, 27.95; $\mathrm{H}, 3.70 ; \mathrm{N}, 6.48$. 


\section{Lead-proline complex}

To a solution of L-proline $(5.0 \mathrm{mmol})$ in $\mathrm{MeOH}(10.0 \mathrm{~mL}), \mathrm{Et}_{3} \mathrm{~N}(0.7 \mathrm{~mL})$ was added and stirred at room temperature. After $10 \mathrm{~min}$, lead acetate $(2.5 \mathrm{mmol})$ was added; the solid which separated after 45 minutes was filtered off and recrystallized.White amorphous solid; Yield $=100 \%$; m.p. $=$ decomposed at $210^{\circ} \mathrm{C}$; $\mathrm{IR}\left(\mathrm{KBr}, \mathrm{cm}^{-1}\right): 3236,2981,2868,1653$, 1571, 1377; ${ }^{1} \mathrm{H}$ NMR $\left(300 \mathrm{MHz}, \mathrm{D}_{2} \mathrm{O}\right): \delta_{\mathrm{H}} 1.93(\mathrm{~m} \mathrm{br}, 3 \mathrm{H}), 2.23(\mathrm{~m} \mathrm{br}, 1 \mathrm{H}), 3.14(\mathrm{~m} \mathrm{br}, 1 \mathrm{H}), 3.23(\mathrm{~m} \mathrm{br}, 1 \mathrm{H}), 3.91(\mathrm{~m} \mathrm{br}$, $1 \mathrm{H}) ;{ }^{33} \mathrm{C}$ NMR $\left(75 \mathrm{MHz}, \mathrm{D}_{2} \mathrm{O}\right): \delta_{\mathrm{C}} 178.3(-\mathrm{CO}), 62.4(-\mathrm{CH}-\mathrm{C}), 49.1\left(-\mathrm{CH}_{2}-\mathrm{C}\right), 47.1\left(-\mathrm{CH}_{2}-\mathrm{NH}\right), 30.6\left(-\mathrm{CH}_{2}-\mathrm{C}\right) ;$ Anal Cald for $\mathrm{C}_{10} \mathrm{H}_{16} \mathrm{~N}_{2} \mathrm{O}_{4} \mathrm{~Pb}: \mathrm{C}, 27.58, \mathrm{H}, 3.70 ; \mathrm{N}, 6.43$. Found: $\mathrm{C}, 27.53, \mathrm{H}, 3.62 ; \mathrm{N}, 6.39$.

\section{4-(4-nitrophenyl)-4-(phenylamino)-butan-2-one (4a)}

Cadmium-proline complex $(0.1 \mathrm{mmol}, 10 \mathrm{~mol} \%)$ was added to a mixture of p-nitrobenzaldehyde $(1 \mathrm{mmol})$, aniline (1.1 $\mathrm{mmol}$ ), and acetone (excess) in $5 \mathrm{~mL}$ of water, then the reaction mixture was stirred at room temperature until the TLC indicated the complete reaction. After completion of the reaction, the organic part was removed by adding ethyl acetate and the aqueous phase was collected for further reaction. The organic part was washed with water $(3 \times 10 \mathrm{~mL})$, dried with anhydrous $\mathrm{Na}_{2} \mathrm{SO}_{4}$ and then filtered. Purified by silica gel column chromatography with ethyl acetate/petroleum ether mixtures as eluen. Brown oil (96\%); IR $\left(\mathrm{cm}^{-1}\right)$ : 3455, 3000, 2922, 1710, 1601, 1517, 1339; ${ }^{1} \mathrm{H} \mathrm{NMR}\left(400 \mathrm{MHz}, \mathrm{CDCl}_{3}\right): \delta_{\mathrm{H}}$ $8.216(4 \mathrm{H}, \mathrm{d}, \mathrm{J}=8.8 \mathrm{~Hz}), 7.54-7.82(5 \mathrm{H}, \mathrm{m}), 5.26-5.29(\mathrm{~m}, 1 \mathrm{H}), 4.09-4.15(\mathrm{~m}, 1 \mathrm{H}), 2.80-2.90(\mathrm{~m}, 2 \mathrm{H}), 2.05-2.09(\mathrm{~s}, 3 \mathrm{H}) ;{ }^{13} \mathrm{C}$ $\operatorname{NMR}\left(100 \mathrm{MHz}, \mathrm{CDCl}_{3}\right): \delta_{\mathrm{C}} 208.5,149.9,126.4,123.7,68.9,51.5,30.7$. Anal. Calcd. for $\mathrm{C}_{16} \mathrm{H}_{16} \mathrm{~N}_{2} \mathrm{O}_{3}: \mathrm{C}, 67.59 ; \mathrm{H}, 5.67 ; \mathrm{N}$, 9.85; Found: C, 67.53; H, 5.65; N, 9.81.

\section{4-(4-nitrophenyl)-4-(4-nitrophenylamino)-butan-2-one (4b)}

Cadmium-proline complex $(0.1 \mathrm{mmol}, 10 \mathrm{~mol} \%)$ was added to a mixture of $\mathrm{p}$-nitrobenzaldehyde $(1 \mathrm{mmol})$, p-nitroaniline $(1.1 \mathrm{mmol})$, and acetone (excess) in $5 \mathrm{~mL}$ of water, then the reaction mixture was stirred at room temperature until the TLC indicated the complete reaction. After completion of the reaction, the organic part was removed by adding ethyl acetate and the aqueous phase was collected for further reaction. The organic part was washed with water $(3 \times 10 \mathrm{~mL})$, dried with anhydrous $\mathrm{Na}_{2} \mathrm{SO}_{4}$ and then filtered. Purified by silica gel column chromatography with ethyl acetate/petroleum ether mixtures as eluen. Yellow oil $(92 \%)$, solidified at low temperature; IR $\left(\mathrm{cm}^{-1}\right): 3470,2923,1715,1599,1523,1342 ;{ }^{1} \mathrm{H}$ NMR $\left(400 \mathrm{MHz}, \mathrm{CDCl}_{3}\right): \delta_{\mathrm{H}} 1.25(\mathrm{~s}, 3 \mathrm{H}), 2.24(\mathrm{~s}, 2 \mathrm{H}), 2.87-2.88(\mathrm{~m}, 2 \mathrm{H}), 3.74(\mathrm{~s}, 1 \mathrm{H}), 7.54-7.56(\mathrm{~m}, 4 \mathrm{H}), 8.19-8.22(\mathrm{~m}$, $4 \mathrm{H}) ;{ }^{13} \mathrm{C} \mathrm{NMR}\left(100 \mathrm{MHz}, \mathrm{CDCl}_{3}\right): \delta_{\mathrm{C}} 208.7,150.0,147.2,126.4,123.8,68.9,51.5,30.8,29.7$; Anal. Calcd. for $\mathrm{C}_{16} \mathrm{H}_{15} \mathrm{~N}_{3} \mathrm{O}_{5}$ : C, 58.36; H, 4.59; N,12.76; Found: C, 58.33; H, 4.55; N,12.74.

\section{4-(4-nitrophenyl)-4-(4-methoxyphenylamino)-butan-2-one (4c)}

Cadmium-proline complex $(0.1 \mathrm{mmol}, 10 \mathrm{~mol} \%)$ was added to a mixture of $\mathrm{p}$-nitrobenzaldehyde $(1 \mathrm{mmol}), \mathrm{p}$-anisidine (135 $\mathrm{mg}, 1.1 \mathrm{mmol}$ ), and acetone (excess) in $5 \mathrm{~mL}$ of water, then the reaction mixture was stirred at room temperature until the TLC indicated the complete reaction. After completion of the reaction, the organic part was removed by adding ethyl acetate and the aqueous phase was collected for further reaction. The organic part was washed with water $(3 \times 10 \mathrm{~mL})$, dried with anhydrous $\mathrm{Na}_{2} \mathrm{SO}_{4}$ and then filtered. Purified by silica gel column chromatography with ethyl acetate/petroleum ether mixtures as eluen. Yellow oil $(90 \%)$; IR $\left(\mathrm{cm}^{-1}\right): 3466,2916,1711,1518,1345 ;{ }^{1} \mathrm{H} \mathrm{NMR}\left(400 \mathrm{MHz}, \mathrm{CDCl}_{3}\right): \bar{\delta}_{\mathrm{H}} 2.25(\mathrm{~s}$, $3 \mathrm{H}), 2.87-2.88(\mathrm{~m}, 2 \mathrm{H}), 3.71(\mathrm{~s}, 3 \mathrm{H}), 4.82(\mathrm{t}, \mathrm{J}=7.5 \mathrm{~Hz}), 6.48(\mathrm{~m}, 2 \mathrm{H}), 6.82(\mathrm{~m}, 2 \mathrm{H}), 7.54(\mathrm{~m}, 2 \mathrm{H}), 8.18(\mathrm{~m}, 2 \mathrm{H}) ;{ }^{13} \mathrm{C} \mathrm{NMR}$ $\left(100 \mathrm{MHz}, \mathrm{CDCl}_{3}\right): \delta_{\mathrm{C}} 207.4,152.0,150.3,147.6,127.4,123.8,117.2,115.8,114.8,55.8,55.6,51.2$, 30.8; Anal. Calcd. for $\mathrm{C}_{17} \mathrm{H}_{18} \mathrm{~N}_{2} \mathrm{O}_{4}$ : C, 64.96; $\mathrm{H}, 5.77 ; \mathrm{N}, 8.91$; Found: C, 64.92; $\mathrm{H}, 5.68 ; \mathrm{N}, 8.88$.

\section{4-(4-methoxyphenyl)-4-(4-methoxyphenylamino)-butan-2-one (4d)}

Cadmium-proline complex $(0.1 \mathrm{mmol}, 10 \mathrm{~mol} \%)$ was added to a mixture of $\mathrm{p}$-methoxybenzaldehyde $(1 \mathrm{mmol}), \mathrm{p}$-anisidine $(135 \mathrm{mg}, 1.1 \mathrm{mmol})$, and acetone (excess) in $5 \mathrm{~mL}$ of water, then the reaction mixture was stirred at room temperature until the TLC indicated the complete reaction. After completion of the reaction, the organic part was removed by adding ethyl acetate and the aqueous phase was collected for further reaction. The organic part was washed with water $(3 \times 10$ $\mathrm{mL}$ ), dried with anhydrous $\mathrm{Na}_{2} \mathrm{SO}_{4}$ and then filtered. Purified by silica gel column chromatography with ethyl acetate/petroleum ether mixtures as eluen. Yellow oil (88\%); IR $\left(\mathrm{cm}^{-1}\right): 3466,2916,1711,1518,1345 ;{ }^{1} \mathrm{H} \mathrm{NMR}(400 \mathrm{MHz}$, $\left.\mathrm{CDCl}_{3}\right): \delta_{\mathrm{H}} 2.35(\mathrm{~s}, 3 \mathrm{H}), 2.78(\mathrm{~m}, 2 \mathrm{H}), 3.74(\mathrm{~s}, 3 \mathrm{H}), 3.82(\mathrm{~s}, 3 \mathrm{H}), 4.86(\mathrm{t}, \mathrm{J}=7.5 \mathrm{~Hz}), 6.53-6.61(\mathrm{~m}, 2 \mathrm{H}), 6.72-6.78(\mathrm{~m}, 2 \mathrm{H})$, 7.12-7.24 (m, 2H), 7.30-7.34 (m, 2H); ${ }^{13} \mathrm{C}$ NMR (100 MHz, $\left.\mathrm{CDCl}_{3}\right): \delta_{\mathrm{C}} 208.4,159.0,152.8,140.6,131.7,128.8,116.4$, 115.2, 114.5, 81.3, 59.1, 56.0, 55.6, 25.8; Anal. Calcd. for $\mathrm{C}_{18} \mathrm{H}_{21} \mathrm{NO}_{3}$ : C, 72.22; H, 7.07; N,4.68; Found: C, 72.14; $\mathrm{H}, 7.12$; $\mathrm{N}, 4.72$.

\section{3-(4-methoxyphenylamino)-3-(4-nitrophenyl)methyl)-pentane-2,4-dione (4e)}

Cadmium-proline complex $(0.1 \mathrm{mmol}, 10 \mathrm{~mol} \%)$ was added to a mixture of $\mathrm{p}$-nitrobenzaldehyde $(1 \mathrm{mmol}), \mathrm{p}$-anisidine (135 $\mathrm{mg}, 1.1 \mathrm{mmol})$, and acetylacetone $(1 \mathrm{mmol})$ in $5 \mathrm{~mL}$ of water, then the reaction mixture was stirred at room temperature until the TLC indicated the complete reaction. After completion of the reaction, the organic part was removed by adding ethyl acetate and the aqueous phase was collected for further reaction. The organic part was washed with water $(3 \times 10$ $\mathrm{mL})$, dried with anhydrous $\mathrm{NaSO}_{4}$ and then filtered. Purified by silica gel column chromatography with ethyl acetate/petroleum ether mixtures as eluen.Yellow crystal (85\%); m.p.=198-199 ${ }^{\circ} \mathrm{C}$; IR $\left(\mathrm{cm}^{-1}\right): 3500,2974,1704,1517$, 1349, 1167; ${ }^{1} \mathrm{H}$ NMR $\left(400 \mathrm{MHz}, \mathrm{CDCl}_{3}\right): \delta_{\mathrm{H}} 9.07$ (br s,1H), 8.07-8.09 (m,4H), 7.38-7.40 (m,4H), 5.19 (1H,m), 3.32 (d, $2 \mathrm{H}$, $J=9.6), 2.31(\mathrm{~s}, 3 \mathrm{H}), 2.21(\mathrm{~s}, 3 \mathrm{H}) ;{ }^{13} \mathrm{C} N \mathrm{NMR}\left(100 \mathrm{MHz}, \mathrm{CDCl}_{3}\right): \delta_{\mathrm{C}} 214.5,198.8,180.1,151.9,128.6,124.6,108.9,69.2$, 63.2, 44.2, 34.9, 27.8. Anal. Calcd. for $\mathrm{C}_{19} \mathrm{H}_{20} \mathrm{~N}_{2} \mathrm{O}_{5}$ : C, 64.04; $\mathrm{H}, 5.66 ; \mathrm{N}, 7.86$; Found: $\mathrm{C}, 63.99 ; \mathrm{H}, 5.63 ; \mathrm{N}, 7.84$. 


\section{2-(4-nitrophenyl)-2-(phenylamino)methyl-cyclooctanone (4f)}

Cadmium-proline complex $(0.1 \mathrm{mmol}, 10 \mathrm{~mol} \%)$ was added to a mixture of $\mathrm{p}$-nitrobenzaldehyde $(1 \mathrm{mmol}), \mathrm{p}$-anisidine (1.1 $\mathrm{mmol})$, and cyclooctanone $(1 \mathrm{mmol})$ in $5 \mathrm{~mL}$ of water, then the reaction mixture was stirred at room temperature until the TLC indicated the complete reaction. After completion of the reaction, the organic part was removed by adding ethyl acetate and the aqueous phase was collected for further reaction. The organic part was washed with water $(3 \times 10 \mathrm{~mL})$, dried with anhydrous $\mathrm{NaSO}_{4}$ and then filtered. Purified by silica gel column chromatography with ethyl acetate/petroleum ether mixtures as eluen. Yellow solid (55\%); m.p. $=148-150^{\circ} \mathrm{C}$; IR $\left(\mathrm{cm}^{-1}\right)$ : 3403, 3078, 2936, 2866, 1688, 1598, 1521; ${ }^{1} \mathrm{H}$ $\operatorname{NMR}\left(400 \mathrm{MHz}, \mathrm{CDCl}_{3}\right): \delta_{\mathrm{H}} 8.24(\mathrm{~d}, 2 \mathrm{H}, \mathrm{J}=8.7 \mathrm{~Hz}), 7.49(\mathrm{~d}, 2 \mathrm{H}, \mathrm{J}=8.4 \mathrm{~Hz}), 7.27-7.42(\mathrm{~m}, 5 \mathrm{H}), 2.78(\mathrm{~d}, 1 \mathrm{H}, \mathrm{J}=8.2 \mathrm{~Hz}), 2.17$ (br s, $1 \mathrm{H}), 1.83-1.91(\mathrm{~m}, 4 \mathrm{H}), 1.68-1.78(\mathrm{~m}, 5 \mathrm{H}), 1.48-1.64(\mathrm{~m}, 4 \mathrm{H}) ;{ }^{13} \mathrm{C} \mathrm{NMR}\left(100 \mathrm{MHz}, \mathrm{CDCl}_{3}\right): \delta_{\mathrm{C}} 207.1,147.2,143.7$, 142.8, 133.6, 130.1, 123.7, 39.3, 29.9, 29.5, 26.4, 25.7, 25.6. Anal. Calcd.for $\mathrm{C}_{21} \mathrm{H}_{24} \mathrm{~N}_{2} \mathrm{O}_{3}$ : C, 71.57; $\mathrm{H}, 6.86 ; \mathrm{N}, 7.95 ;$ Found: C, 71.54; H, 6.82; N, 7.93.

\section{N-(2,8-bis(4-nitrobenzyl)cyclooctylidene)aniline (5)}

Colourless solid (45\%); m.p.=162-164 ${ }^{\circ}$; IR $\left(\mathrm{cm}^{-1}\right)$ : 3072, 2920, 1598, 1521; ${ }^{1} \mathrm{H}$ NMR $\left(400 \mathrm{MHz}, \mathrm{CDCl}_{3}\right): \delta_{\mathrm{H}} 8.23(\mathrm{~d}, 2 \mathrm{H}$, $\mathrm{J}=8.7 \mathrm{~Hz}), 8.18(\mathrm{~d}, 2 \mathrm{H}, \mathrm{J}=8.4 \mathrm{~Hz}), 8.15(\mathrm{~d}, 2 \mathrm{H}, \mathrm{J}=8.4 \mathrm{~Hz}), 7.48-7.53(\mathrm{~m}, 2 \mathrm{H}), 7.06-7.26(\mathrm{~m}, 5 \mathrm{H}), 3.05-3.09(\mathrm{~m}, 1 \mathrm{H}), 2.74(\mathrm{~d}$, $1 \mathrm{H}, \mathrm{J}=8.2 \mathrm{~Hz}), 2.32-2.38(\mathrm{~m}, 1 \mathrm{H}), 2.17-2.22(\mathrm{~m}, 1 \mathrm{H}), 2.07-2.12(\mathrm{~m}, 2 \mathrm{H}), 1.35-1.44(\mathrm{~m}, 4 \mathrm{H}), 1.61-1.75(\mathrm{~m}, 4 \mathrm{H}), 1.82-1.87$ $(\mathrm{m}, 2 \mathrm{H}) ;{ }^{13} \mathrm{C}$ NMR $\left(100 \mathrm{MHz}, \mathrm{CDCl}_{3}\right): \delta_{\mathrm{C}} 171.4,150.2,146.7,146.3,143.3,142.4,131.3,130.0,129.2,128.9,124.7$, 123.8, 119.6, 118.3, 113.6, 59.9, 56.2, 44.0, 39.9, 30.4, 27.7, 26.6, 26.0, 25.0, 24.8. Anal. Calcd.for $\mathrm{C}_{28} \mathrm{H}_{29} \mathrm{~N}_{3} \mathrm{O}_{4}$ : C, 71.32; H, 6.20; N, 8.91; Found: C, 71.36; H, 6.42; N, 8.68.

\section{RESULTS AND DISCUSSION}

Metal-proline complexes were first prepared by adding $\mathrm{Et}_{3} \mathrm{~N}(0.7 \mathrm{~mL})$ to a mixture of L-proline $(5.0 \mathrm{mmol})$ in $\mathrm{MeOH}(10.0$ $\mathrm{mL})$; after $10 \mathrm{~min}$, metal acetate $(2.5 \mathrm{mmol})$ was added. After stirring for 45 minutes, a white precipitate was collected by filtration. Complexes were characterized by NMR, IR, and ESI-MS. X-ray patterns of the prepared metal-proline complexes were recorded at $2 \Theta=0-100$ range and are shown in figure 1 . The crystalline size of the proline complexes of metals like $\mathrm{Cd}, \mathrm{Hg}$, and $\mathrm{Pb}$ were found to be $29.19,28.41$, and $30.79 \mathrm{~nm}$, respectively, which were calculated by using Debye-Scherrer formula [21, 22]. The PXRD pattern of Pb-proline complex was matched with the data card [23] 00-0481161 PDF2, the peaks revealed that the crystal is monoclinic in shape.

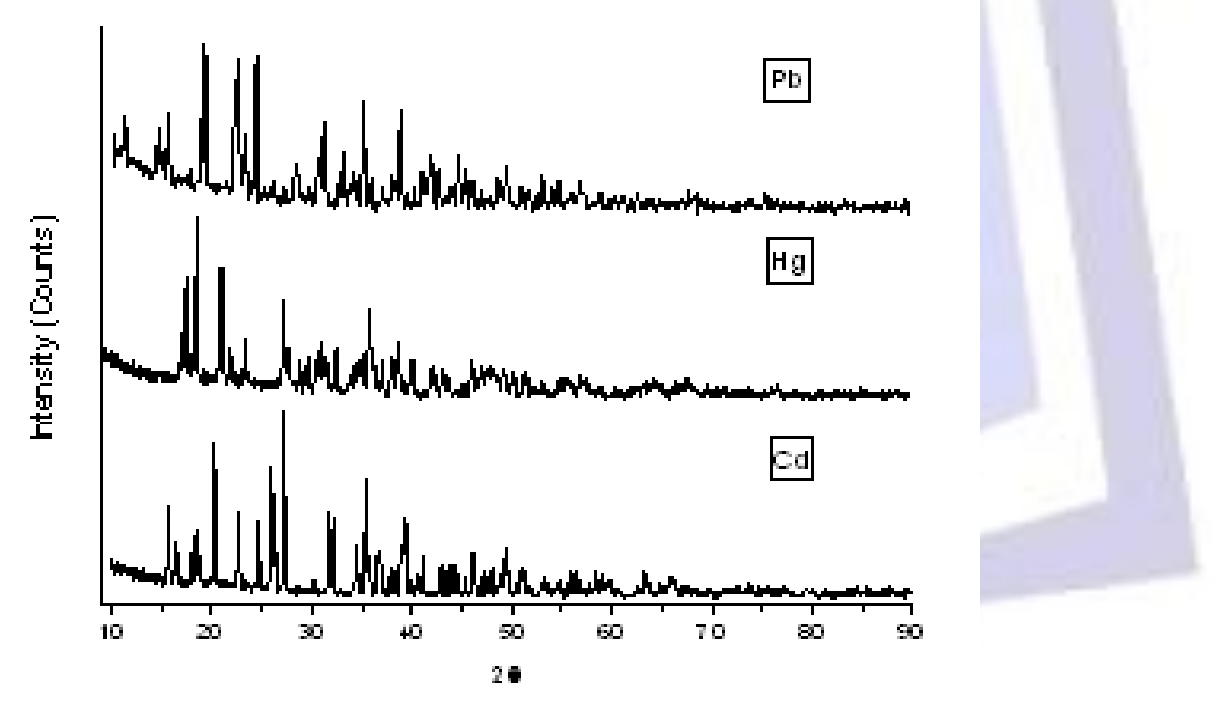

Figure1. PXRD pattern of metal-proline complexes

The metal-proline complexes on excitation at $\lambda 424$ gave two excitation wavelengths at 237 and $424 \mathrm{~nm}$. The emission spectra were taken on $\lambda_{\text {exc }} 424$, at the range of $400-750 \mathrm{~nm}$, Filter 450 and Slith Width of 2.5 found emission spectra at $607 \mathrm{~nm}$. The emission spectrum for Cd-proline complex was found unchanged after recovered from the reaction medium which shows that structure of the catalyst remain unchanged after the reaction. The results of UV and XRD pattern of the prepared metal-proline complexes are shown in Figure 2 and 3, respectively. 


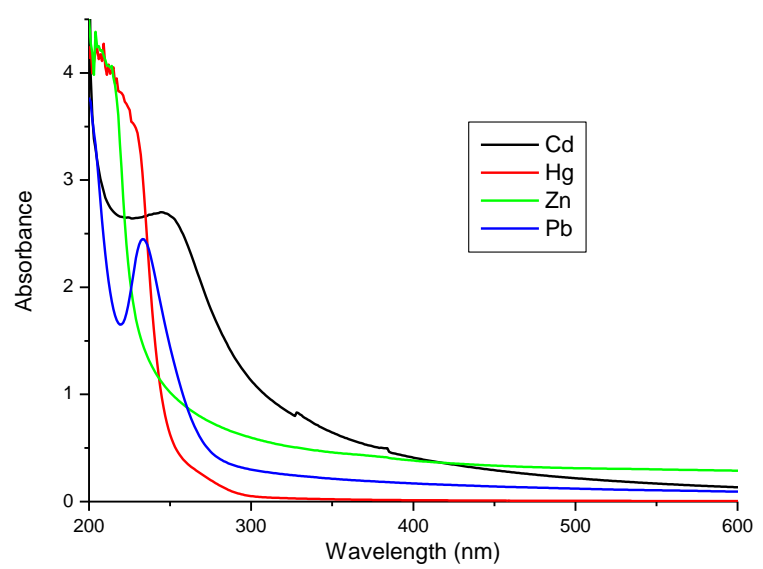

Figure 2: UV visible spectra of metal-proline complexes

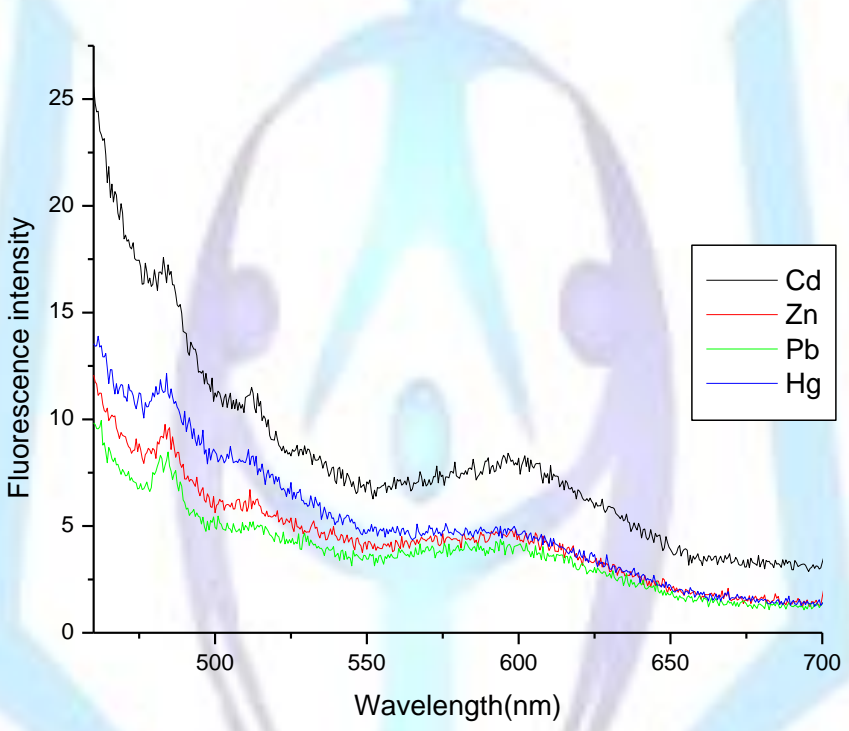

Figure3: Fluorescence Spectra of metal-proline complexes ( $\lambda_{\text {exc }} 247 \mathrm{~nm}$ )

The direct one-pot three component Mannich reaction of various aldehydes, amines and ketones were studied in presence of metal-proline complexes in water medium. The effect of the concentration of catalyst for $\mathrm{Cd}$-proline complex in different substrates were studied; mainly the concentration of catalyst were found to be good in $10 \mathrm{~mol} \%$, and the results in effect on yields were shown in figure 4 . Thus we have selected the $10 \mathrm{~mol} \%$ of catalyst for direct three component Mannich reactions for the ongoing research work.

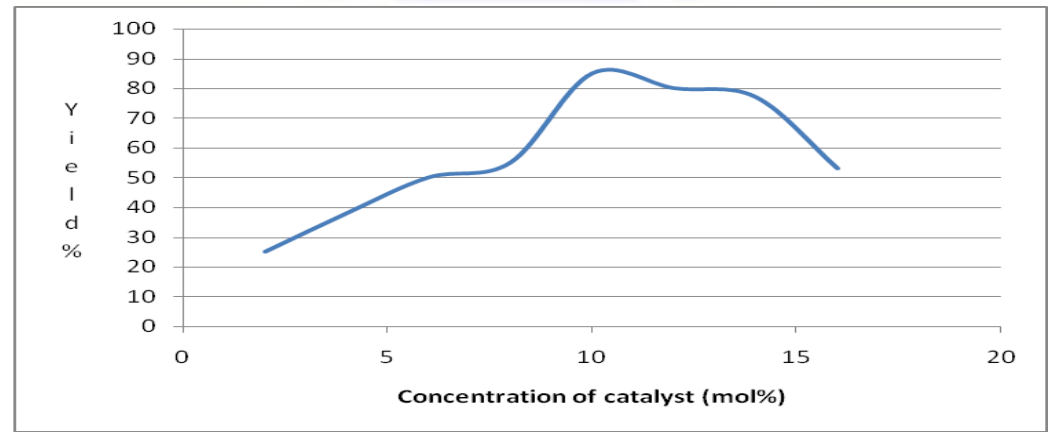

Figure 4. Effect of concentration of catalyst on yield

The one pot three component Mannich reactions of $p$-anisidine $(1.0 \mathrm{mmol}), p$-nitrobenzaldehyde $(1.0 \mathrm{mmol})$ and acetone (excess) in water $(5 \mathrm{~mL})$ in presence of metal-proline complexes $(0.1 \mathrm{mmol})$ gave Mannich product in good to excellent 
yields. Among the catalysts, Cd-proline complex gave high yield as compared to the other catalysts; the results are summarized in table 1.

Table 1. Metal-proline complex catalyzed three component Mannich reaction of $p$-anisidine, $p$-nitrobenzaldehyde and acetone in water at room temperature ${ }^{\mathrm{a}}$

\begin{tabular}{|c|c|c|c|}
\hline Entry & $\begin{array}{c}\text { Catalyst } \\
\text { (metal-proline complex) }\end{array}$ & Yield $^{\mathrm{b}}(\%)$ & Time $^{\mathrm{c}}$ (min.) \\
\hline 1 & $\mathrm{Cd}$ & 96 & 48 \\
\hline 2 & $\mathrm{Zn}$ & 82 & 48 \\
\hline 3 & $\mathrm{Hg}$ & 73 & 52 \\
\hline 4 & $\mathrm{~Pb}$ & 77 & 56 \\
\hline
\end{tabular}

${ }^{a}$ Reaction condition: Metal-proline complex(10mol\%), $p$-anisidine(1millimole),p-nitrobenzaldehyde (1milimole) and excess acetone in $5 \mathrm{~mL}$ water at room temperature.

${ }^{b}$ Isolated Yields.

${ }^{\mathrm{c}}$ Reaction Progress monitored by TLC.

From the above results, we take the cadmium-proline complex as the catalyst of choice for direct Mannich reaction and investigate its catalytic activity in different solvents at different temperatures. At first, we compared the yield of direct Mannich reaction of $p$-anisidine $(1.0 \mathrm{mmol}), p$-nitrobenzaldehyde $(1.0 \mathrm{mmol})$ and acetone (excess) catalyzed by cd-proline complex $(0.1 \mathrm{mmol}, 10 \mathrm{~mol} \%)$ in water and DMSO as solvent. The yield of the product was found to be $56 \%$ in water whereas in DMSO decreases up to $25 \%$ in 48 hours. Whereas the same reaction under solvent less condition, the product was found to be $47 \%$ yield only in 92 hours. The reaction of $p$-nitrobenzaldehyde, aniline and acetone and the catalyst 10 mol\% in water gave $60 \%$ yield in 48 hours; whereas the same reaction in $\mathrm{MeOH}$ at $45^{\circ} \mathrm{C}$, yield was found to be $21 \%$ only in 50 hours. The above experiment shows that the catalyst is well operating in water medium and room temperature condition is suitable for the reaction. Herein, we report the Mannich reaction of various ketones, aldehydes and amines in presence of $10 \mathrm{~mol} \%$ of the catalyst in water at room temperature condition (Scheme 1).

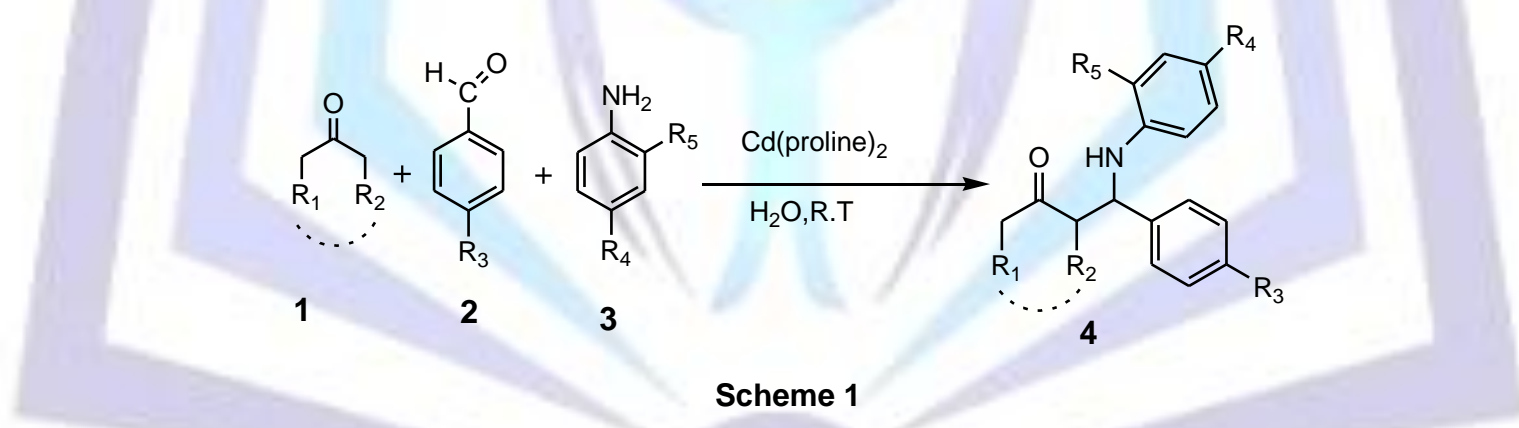

The one pot three component Mannich reactions of several substituted ketones 1, aldehydes 2 and amines $\mathbf{3}$ in presence of cd-proline complex $(10 \mathrm{~mol} \%)$ in water medium at room temperature were investigated and the Mannich products 4 were isolated by simple extraction of the crude products and the results were summarized in table 2.

Table 1. Three component Mannich reactions of various ketones, aldehydes and amines in presence of $10 \mathrm{~mol} \%$ of Cd-proline complex in water ${ }^{\text {a }}$

\begin{tabular}{|c|c|c|c|}
\hline Entry & Product (4) & Yield $^{\text {(\%) }}$ & Time $^{c}$ (hr.) \\
\hline 1 & & 96 & \\
\hline
\end{tabular}




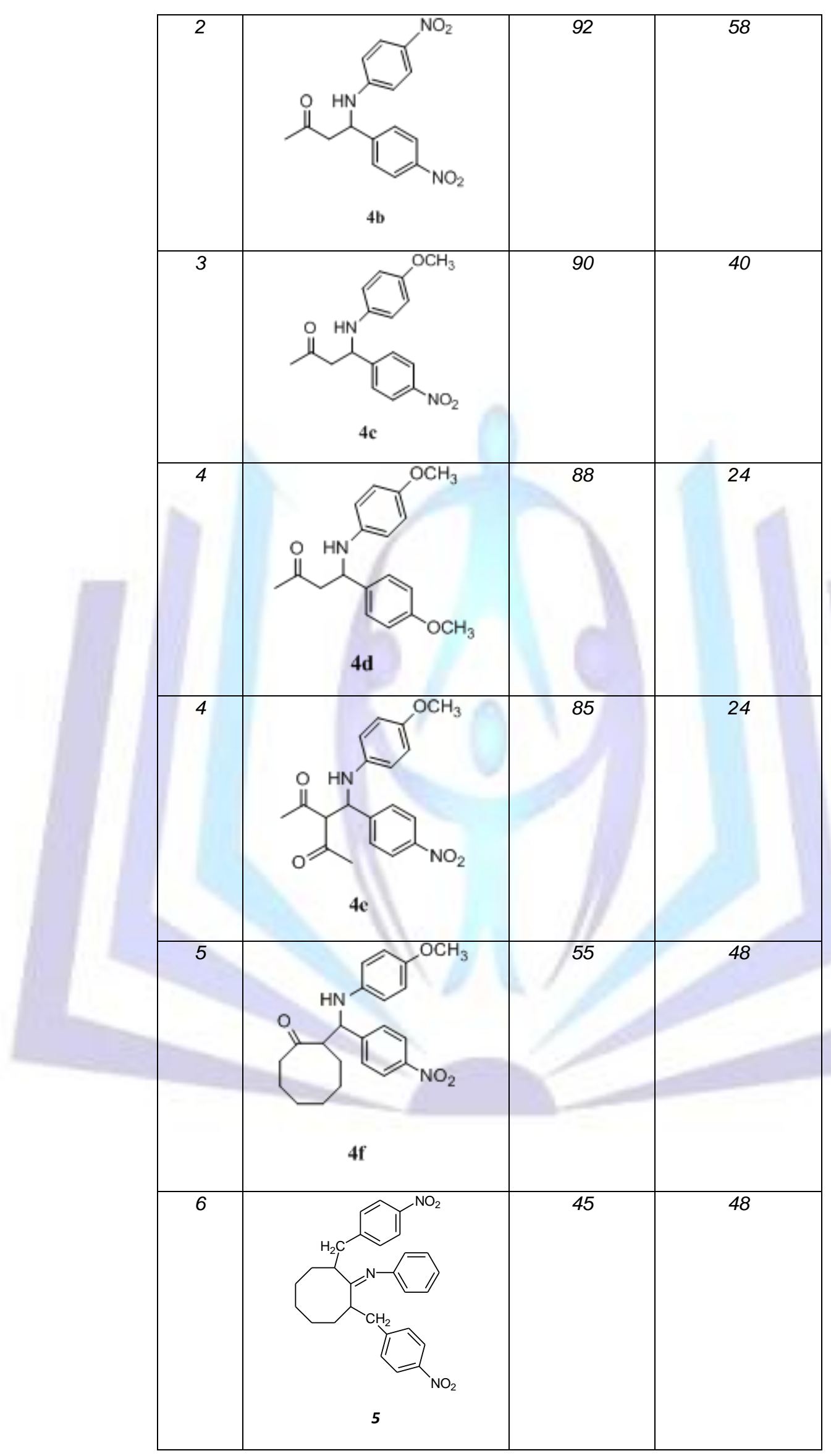


Cd-proline complex $(0.1 \mathrm{mmol}, 10 \mathrm{~mol} \%)$ was added to a mixture of aldehyde $(1.0 \mathrm{mmol})$, amine $(1.0 \mathrm{mmol})$ and ketone $(1.0 \mathrm{mmol}) /$ acetone (excess) in water $(5.0 \mathrm{~mL})$ and then the reaction mixture was stirred at room temperature for several hours. The Mannich product 4a (entry 1) was obtained as $96 \%$ yield in 48 hours. The Mannich reaction of acetone, $p-$ nitrobenzaldehyde and $p$-nitroaniline gave Mannich product $\mathbf{4 b}$ (entry 2) in $92 \%$ in 58 hours. When $p$-anisidine was used, the product 4c (entry 3 ) was found to be $90 \%$ yield in 40 hours. Whereas the reaction of $p$-methoxy substituted aldehyde and $p$-anisidine was used as Mannich acceptors, the product 4d (entry 4) was found to be $88 \%$ yield only in 24 hours. The Mannich reaction of acetyl acetone, $p$-nitrobenzaldehyde and $p$-anisidine proceeded to give Mannich product $4 \mathbf{e}$ (entry 5 ) in an excellent yield $85 \%$ in 24 hours; whereas the same reaction with cyclooctanone using $p$-anisidine gave product $\mathbf{4 f}$ (entry 6 ) in $55 \%$ yield only in 48 hours. When cyclooctanone was used as Mannich donor in three component Mannich reaction of $p$-nitrobenzaldehyde and aniline, an interesting side product (5) was found, the crystal structure of the compound (CCDC No.918946) was given in figure 5.

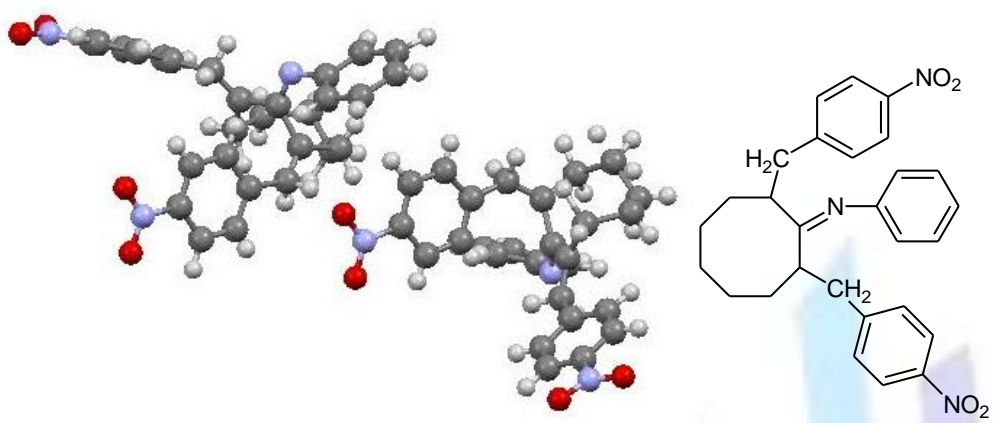

Figure 5. ORTEP and molecular structure of 5

When the reaction of different ketones, like 3-pentanone, 2-pentanone and isobutyl methyl ketone were used as Mannich donors in water medium, the reactions could not proceed to give the corresponding Mannich products in 144 hours (6 days).

In conclusion, we have synthesized the metal-proline complexes in a simple atom economic procedure. The small amount of the catalyst $(0.1 \mathrm{mmol})$ was found to be an efficient catalyst for the asymmetric three component Mannich reaction at room temperature in water. Since the catalysts were soluble in water, they could be recovered by simple aqueous extraction method and were reusable for further synthesis without losing its catalytic quality. It was found that all the reactions could be carried out at room temperature condition, the procedure was very simple and energy saving. Further development of the catalytic activities of these metal-proline complexes in stereoselective strategies for the direct three component Mannich reactions is under investigation.

\section{ACKNOWLEDGMENTS}

We acknowledge the DST, New Delhi for financial support; and IIT, Guwahati, SAIF NEHU, Shillong, and CDRI, Lucknow for spectral data.

\section{REFERENCES}

[1] G. Vasuki, K. Kumaravel, Tetrahedron Lett. 2008, 49, 5636-5638.

[2] J.S.Yadav, B.V.S. Reddy, P. Sridhar, J.S.S. Reddy, K. Nagaiah, N. Lingaiah, P.S. Saiprasad, Eur. J. Org.Chem. 2004, 3, 552-557.

[3] R. Maggi, R. Ballini, G. Sartori, R. Sartorio, Tetrahedron Lett. 2004, 45, 2297-2299.

[4] T.-S. Jin, A.-Q. Wang, X. Wang, J.-S. Zhang, T.-S. Li, Synlett 2004, 35, 871-873.

[5] U. M. Lindstorm, Chem. Rev. 2002, 102, 2751-2752.

[6] B.N. Richard, C.G. Anthony, Chem. Rev. 2010, 110, 6302-6337.

[7] N.Shapiro, A. Vigalok, Angew.Chem. Int.Ed. 2008, 47, 2849-2852.

[8] Q. Lin, J.C. O’Neill, H.E. Blackwell, E. Org. Lett. 2005, 7, 4455-4458.

[9] C .Mannich, W. Krosche, Arch. Pharm. 1912, 250, 647-667.

[10] R. Muller, H. Goesmann, H. Waldmann, Angew. Chem., Int. Ed. 1999, 38, 184-187.

[11] W. Notz, F. Tanaka, S. Watanabe, N.S. Chowdari, J.M. Turner, R. Thayumanavan, C.F. Barbas, J. Org. Chem. 2003, $68,9624-9634$.

[12] N. Azizi, L. Torkiyan, M. R. Saidi, Org. Lett. 2006, 8, 2079-2082.

[13] F. Dong, L. Jun, X.-L. Zhou, Z.-L. Liu, Catalysis Letters 2007, 116, 76-80. 
[14] K. Li, T. He, C. Li,X.-W. Feng, N. Wang, X.-Q. Yu, Green Chem. 2009, 11, 777-779.

[15] Y. Hayashi, T. Urushima, S. Aratake, T. Okano, K. Obi, Org. Lett. 2008, 10, 21-24.

[16] L. Cheng, X. Wu, Y. Lu, Org. Biomol. Chem. 2007, 5, 1018-1020.

[17] S. Kobayashi, T. Hamada, K. Manabe J. Am. Chem. Soc. 2002, 124, 5640-5641.

[18] A. Cordova, C.F. Barbas, Tetrahedron Lett. 2003, 44, 1923-1926.

[19] T. Darbre, M. Machuqueiro, Chem. Commun. 2003, 1090-1091.

[20] M.M Heravi, A. Ghods, K. Bakhtiari, F. Derikvand, Synth. Commun. 2010, 40, 1927-1931.

[21] M. Kidwai, A. Jain, R. Poddar, J. Organometallic Chem. 2011, 696, 1939-1044.

[22]J. Lal, M. Sharma, S. Gupta, P. Parashar, P. Sahu, D.D. Agarwal, J. Mol. Catl. A: Chem. 2012, 352, 31-37.

[23] H.-L. Choi, N. Ishizawa, N. Enomoto, Z.-e.Nakagawa, Powder Diffraction 1996, 11, 7. 